Radenko ŠĆEKIĆ

Viši naučni saradnik

Istorijski institut

Univerziteta Crne Gore
Pregledni naučni rad

UDK: 341.231 .14

Primljeno:19.1.2020.

Prihvaćeno:13.2.2020.

https://doi.org/10.47152/rkkp.58.1.2.5

\title{
UPOTREBA LJUDSKIH PRAVA U GEOPOLITIČKE SVRHE
}

Korpus ljudski prava se široko koristio i koristi u cilju ostvarivanja željenih geopolitičkih interesa. U te svrhe se koriste masovni mediji, ekonomske sankcije, hibridni rat, humanitarne vojne intervencije. U tom kontekstu, zaštita ljudskih prava postaje formalni temelj intervencionizma, kojim se oblikuju političke prilike u brojnim državama. Putem medijskog promovisanja univerzalnih normi ljudskih prava i sloboda i stavljanjem ciljanog fokusa na one koji ih se ne pridržavaju, putem masovnih medija se pripremao teren za potencijalne politicke i vojne akcije. Geopoliticke promjene $i$ Velike sile u skladu sa svojim partikularnim interesima, utiču na upotrebu ljudskih prava, kao povoda za intervencije u druge države. Intervencije toga tipa su često protivne međunarodnom pravu i poveljom UN.

Ključne reči: ljudska prava, geopolitika, mediji, humanitarne intervencije, međunarodno pravo.

\section{Geopolitičke promjene na globalnoj, ,šahovskoj tabli“6}

Klasičnu geopolitiku su koncipirali Evropljani za ostvarivanje pretežno evropocentričnih interesa. ${ }^{11}$ Globalno iznenađenje predstavlja raspad SSSR-a i vojne organizacije Varšavskog ugovora. Vojno-politički blok NATO, formiran

\footnotetext{
*_e-mail: scekicr@yahoo.com

1 „Međutim, Evropljani su na zemljinoj kugli manjina, a istorija evropskog kolonijalizma u sebi sadrži toliki broj zločina, laži i ljudske patnje da je u pravu bio Mahatma Gandi koji je, kada su ga
} 
1949. radi „ograničavanja“ SSSR, od početka 90-ih godina dosledno se pomjera ka granici Ruske Federacije, ignorišući njene geopolitičke interese, kreirajući novi globalni poredak. Uprkos obećanjima datim Mihailu Gorbačovu, NATO se nakon ere Hladnog rata proširio na Istok, uključujući u svoj sastav i neke od bivših sovjetskih republika (Čehulić, 2010: 162). Tako je ušao u prostor koji Rusija smatra „zonom svojih zaštićenih interesa i svoga prava“. Generalni sekretar NATO-a Manfred Verner, u govoru od 17. 5. 1990. u Briselu, rekao je sledeće: „Sama činjenica da nismo spremni da NATO trupe razmještamo dalje od teritorije Federalne Republike (Njemačke) Sovjetskom Savezu pruža čvrste bezbjedonosne garancije". ${ }^{2}$ Sam NATO je priznao da se tako mogu interpretirati neke izjave vodećih političara Zapada toga vremena, ali da se to nikad nije pretvorilo u legalno, pravno obavezujući pismeni ugovor.

Monopolarizam koji se stvorio tokom 90-tih godina 20. vijeka kroz ideju Novog svjetskog poretka, SAD kao jedine preostale globalne supersile i ujedinjenje Njemačke kao ekonomske sile (koja je težila da ekonomsku nadmoć u Evropi potkrijepi i političkim uticajem i ambicijama nakon ujedinjenja), nametali su nova pravila igre. Dž. Fridman, šef obaveštajno-analitičke agencije „Stratfor“ ističe da su SAD u poslednjih 100 godina vodili vrlo doslednu spoljnu politiku, čiji je glavni cilj - ne dozvoliti nijednoj sili da stekne suviše veliku vlast u Evropi. Treba reći da su SAD uvijek smatrale da najveća opasnost prijeti od potencijalnog saveza Rusije i Nemačke. Ruska Federacija nastoji da povrati svoj uticaj na raznim tačkama planete i kroz vidove ekonomskih i političkih integracija i saveza poput ZND (Zajednice Nezavisnih Država) i Evroazijske unije ili BRIKS (ekonomskog povezivanja: Brazil-Rusija-Indija-Kina-JužnaAfrika), u epohi koja se često naziva ,postameričkom“. BRIKS je najveće tržište na planeti, jer ga čini 2,9 milijardi ljudi ili oko $40 \%$ globalne populacije.

Može se iznijeti i stav da su simboličke konstrukcije i teze, poput „sukoba civilizacija“ i sličniih, trebale da pomogne Zapadu (u prvom redu SAD) koje su se nakon pada komunizma, našle u krizi identiteta, da se definiše pomoću novog neprijatelja, odnosno „nove prijetnje“. Tako je dotadašnjeg glavnog neprijatelja, komunizam, odnosno SSSR, kao njegovu personifikaciju trebalo zamijeniti „novim neprijateljem“- islamskom civilizacijom. Jer je Sjeveroatlanskom vojnom savezu (NATO) bilo neophodno da se pod hitno iznađe i ,stvori novi neprijatelj Zapadne civilizacije i kulture" u svrhe opravdanja postojanja pakta. Kreirajući nakon završetka Hladnog rata, nove "iskonske" neprijatelje Zapada i "demokratskog svijeta",

pitali što misli o evropskoj civilizaciji, odgovorio da bi to „bila dobra ideja“ (da civilizacija u Evropi uopše i postoji, prim. aut) - više u Kovačević, 2005:15-21.

2 Više na: NATO (2014) Встреча на высшем уровне 1990 года: поворотный момент в отношениях между Востоком и Западом. - dostupno na: https://www.nato.int/cps/ru/natohq/ news_116133.htm?selectedLocale=ru, stranici pristupljeno 11.6.2019. 
zapadni geopolitički planeri su markirali islamske države kao "pogodne" za novu ulogu i zamjenu za nekadašnje komunističke države "istočnog lagera". Tako je Šiitski Iran proglašen „osovinom zla“, dok su režimi u Libiji, Siriji, Egiptu okarakterisani kao „nedemokratski i diktatorski“.

Zanimljivo je istaći da Japan danas predstavlja globalno ekonomskog i tehnološkog diva, a sa druge strane: političkog ,patuljka“ zavisnog od SAD pod čijom se okupacijom nalazio sve do 1952. Slično kao Velika Britanija, izolacija i odsječenost od kontinenta iz koje proizlazi okretanje prema sebi, ili vječna želja za osvajanjem kopna koja je temeljna pretpostavka imperijalizma, su diskursi utkani u geopolitičku kulturu Japana.

Na diplomatskom planu, Indija traži način da se drži srednjeg puta pomažući izgradnju multipolarnog svijeta. Ona sebe vidi kao jednu od nekoliko nezavisnih sila i regionalnih geopolitičkih igrača koje će se u budućnosti uzajamno balansirati. Zato i umnožava sporazume i dogovore sa drugim glavnim akterima. Indijski geopolitičari govore o potrebi za sve većom Indijom koja bi imala dominantnu poziciju na području koje se proteže od Irana do Tajlanda. Britansko kolonijalno nasleđe je na Indijskom podkontinentu ostavilo krizno žarište u vidu etničkih i religijskih sukoba Indija-Pakistan, Šri Lanci i sl., ali i borba za prevlast i uticaj u regionu između dva ekonomska "džina” Indije i Kine.

Globalna dominacija SAD dostigla je svoj zenit bombardovanjem tadašnje Jugoslavije 1999. Vojnim intervencijama u Avganistanu 2001. i Iraku 2003., izazivanjem tzv. Arapskih proleća 2011., intervencijama u Libiji i Siriji, organizovanje smjene vlasti u Ukrajini 2014. Američka administracija na čelu s Bušom i potpredsjednikom Čejnijem (koja je zvanično vladala SAD od 2001. do 2009.) imala je kristalno jasno stratešku misiju: ostvariti kontrolu nad prostorom Evroazije koja je bogata mineralima i to kroz odvajanje Rusije i Kine, postavljanjem lanca vojnih baza od Bliskog istoka do Gruzije, te kontrolisanjem naftovoda na cjelokupnom evroazijskom kontinentu. U Pentagonu je vojni establišment taj plan nazvao "dominacijom punog spektra" koja podrazumijeva kontrolu kopna, mora i vazdušnog prostora, svemira pa čak i kibernetskog prostora. ${ }^{3}$ Izborom prvog tamnoputog predsjednika u istoriji SAD, Baraka (Huseina) Obame (2009-2017), euforično je iz raznih svjetskih krugova isticana nada, da će se tradicija američkog militarizma i intervencija prekinuti. Međutim, iako je čak dobio i Nobelovu nagradu za mir (kako su isticali kritičari: "za nešto što neće učiniti”), Obama je nastavio politiku svojih prethodnika, poslavši dodatnih 30.000 vojnika u Avganistan, a povodom agresije na Libiju, u duhu "humanitarnog interven-

3 Irak je bio u središtu te strategije, gdje je i izvršena vojna invazija 2003., a dvije godine ranije zauzet je Avganistan. Preko Turske, Balkana,, Ukrajine, Poljske do Baltika, trebalo je vojnim bazama okružiti protivnika (Engdahl, 2009). 
cionalizma" izjavio: "Neke nacije mogu da pasivno posmatraju zlodjela, ali ne $i$ Amerikanci" (Šćekić, 2019).

Novi momenti na globalnoj sceni: ekonomska kriza, Ruska intervencija u Gruziji 2008., građanski rat na istoku Ukrajine i prisajedinjenje poluostrva Krim Ruskoj Federaciji, politički poraz Zapada u Siriji, politička kriza u EU, Bregzit, ekonomsko-političko jačanje i povezivanje Rusije i Kine, kao i regionalnih igrača poput Irana, Turske, Sjeverne Koreje - imaju za posledicu opadanje globalne moći Zapada. ${ }^{4}$ Kako na ekonomskom i vojnom, tako i na kulturno-ideološkom polju. Hibridni, sajber ratovi, mediji kao bojno polje, u epohi „kontrolisanog haosa“ usložnjavaju i dodatno komplikuju savremenu geopolitičku sliku. Borba u samim SAD između Trampove administracije i tzv. „duboke države“, ${ }^{5}$ preliva se i na globalni nivo.

Kroz Strategiju nacionalne bezbjednosti SAD prepoznaje Kinu i Rusiju kao akutne prijetnje što se ogleda i u ponovnom pokretanju Odbora za aktuelnu opasnost, koji je u doba Hladnog rata iznalazio razne načine za suprotstavljanje SSSR-u, ali je sada izričito usredsređen na podrivanje Kine koja, kako tvrde članovi odbora, predstavlja egzistencijalnu prijetnju za SAD. Multipolarni svijet koji se stvara u novom milenijumu, umanjuje dominantnu moć SAD i MMF. ${ }^{6}$

4 U svom govoru u Minhenu 2007., Vladimir Putin kritikovao je unipolarnost svijeta uspostavljenu nakon Hladnog rata: „To je svijet sa jednim gospodarom, jednim suverenom, što je opasno i za sve ostale i za samog suverena, jer ga razara iznutra“, rekao je dodavši da je takav poredak „i neprihvatljiv, i nemoguć".

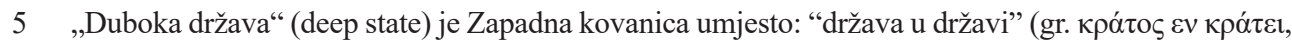
"imperium in imperio", "status in statu", "State within a state"). Duboka država (turski: derin devlet) je izraz koji se koristio prvenstveno u kontekstu turske politike kako bi opisao navodnu čvrstu spregu vrhova vojske, bezbjedonosnih struktura, sudstva i kriminala, odnosno svojevrsnu tajnu vladu koja de facto upravlja zemljom umjesto demokratskih institucija. U evropskim politikama u 19. vijeku, duboku državu definisao je britanski esejista, osnivač časopisa "Ekonomist" Volter Bedžhot, koji uočava da Britanija ima "duplu vladu", "jednu za paradu, fasadu i prihvatanje odluka - koje donosi ona druga - koja zapravo vlada zemljom". Izraz "duboka država" postao je aktuelan u SAD, gdje su se bezbjedonosne službe optuživale za manipulaciju javnošću za vrijeme predsjedničkih izbora 2016. Američki kongresmen Majk Lofgren je još 2014. duboku državu opisao kao "hibridnu asocijaciju dijelova vlade sa finansijskim i privrednim centrima koji su sposobni da samostalno upravljaju državom, sasvim nezavisno od formalnih političkih procesa". On u svojoj knjizi otkriva ko odlučuje u ime vlade SAD: "To je hibrid institucija nacionalne bezbednosti - departmana i agencija za odbranu, unutrašnje bezbednosti, agencija za obavještajne poslove, spoljne poslove, pravdu, dio sudstva i svakako Trezor zbog kontrole finansijskih tokova". Konstanta u svim novijim definicijama bilo gdje na svijetu je: integrisanost različitih dijelova birokratskog aparata u državi, sa dijelovima obavještajnih službi, sudstva i finansija. Ovakve "strukture unutar sistema" sposobne su da sprovedu kroz institucije sistema (ne delujući nužno sa najviših pozicija), onu politiku za koju oni smatraju da je adekvatna.- više o fenomenu "duboke države" (Lofgren, 2014; Goldsmith, 2018).

6 Minhenski izveštaj o bezbjednosti 2017. (Munich Security Report 2017), objavljen uoči istoimene konferencije koji su pripremili razni instituti, svedoči i da je ova, najvažnija međunarodna konferencija o bezbjednosti - zabrinuta. Potpuno je jasan i šef Minhenske konferencije Volfgang Išinger. On već u uvodu tog dokumenta piše da je međunarodna bezbjednost „, ovom trenutku fragilnija nego što je bila ikada od kraja Drugog svjetskog rata“. Nije isključeno da se svijet nalazi i pred ,post-zapadnim“ periodom, što znači da postoji mogućnost da Zapad i njegov liberalni poredak prestanu da postoje”. 
Ekonomska snaga Kine prijeti da potisne SAD sa dominirajuće pozicije glavne svjetske ekonomije. Obnovljena vojna moć Rusije u kombinaciji sa monopolom nad snadbijevanjem energentima i agresivnom medijskom propagandom - umanjuje američku vojnu i političku dominaciju na Bliskom istoku, Balkanu i drugim regionima svijeta. Kroz stvaranje konflikata niskog intenziteta u određenim regionima, vode se posrednički ratovi preko trećih strana. Radi se o hibridnom ratu koji ne prerasta u otvoreni rat, a vodi se putem ekonomskih sankcija, kroz informativni rat na internetu, diskreditovanjem protivnika pred međunarodnom javnošću i organizacijama, vođenjem proxy konflikata manjeg intenziteta.

\section{2. (Zlo)upotreba ljudskih prava}

Živimo (barem formalno i deklarativno) u vremenu ostvarenja ljudskih prava i sloboda. Međutim, korpus tih prava je često podložan manipulisanju i upotrebi u ostvarivanju geopolitičkih ciljeve. Ostvarujući svoje ekonomske i političke interese u procesu globalizacije, vodeće zemlje svijeta su često ostajale bez suštinskih argumenata u procesu realizacije svojih ciljeva, pa se pristupilo korišćenju argumenta o ljudskim pravima, pravima manjina, ugroženih grupa i sl. Ako bi se u određenom trenutku ova grupa pitanja proglasila najznačajnijom i stavila u međunarodni fokus (što se često i dešavalo) - dobijala bi se strateška pregovaračka prednost. Logika je bila pragmatično jednostavna: Što više neku državu kritikuju zbog manjka ljudskih sloboda i prava, ona će lakše otvoriti svoje tržište za firme iz zemalja koje joj prigovaraju iz ,razloga univerzalne prirode“. 7 Ovaj metod se naročito primjenjivao prema Kini, Rusiji, Iranu i dr.

Kraj Prvog svjetskog rata predstavljao vrhunac kolonizacije i moći "bijele" Evrope nad ostatkom svijeta. Superiornost koju su evropski kolonizatori pokazivali prema koloniziranom stanovništvu ogledala se u širokom spektru, od nipodaštavanja, rasne segregacije do fizičke torture i genocida. Brak u SAD izmedju osoba različite rase bio je zakonom zabranjen sve do 1967. Ni "očevi osnivači” SAD krajem 18. vijeka, nisu previše marili za jednakost svih, iako su je deklarativno istcali. ${ }^{8}$ Dok su tokom 19 . vijeka u procesu stvaranja SAD, ljud-

7 Opšta deklaracija o ljudskim pravima i Konvencija o ukidanju svih oblika (rasne) diskriminacije garantuju prava na obrazovanje, medicinsku i socijalnu zaštitu i dostojan standard svakom građaninu. Iako je i sama ratifikovala ove međunarodne konvencije najvišeg značaja, SAD nije usvojila predlog da ekonomska i socijalna prava budu sastavni dio ljudskih prava. Više u Sudar svetova, https://www.vesti.rs/, stranici pristupljeno 17.4.2019.

8 Tomas Džeferson je poznat po rečenici "svi su ljudi stvoreni jednaki” u Deklaraciji o nezavisnosti, ali to nije baš išlo u prilog stotinama njegovih robova koje je posjedovao na svojim plantažama. 
ska prava ${ }^{9}$ bila u drugom planu. ${ }^{10}$ Od kraja 19. veka, kolonijalnoj dominaciji nad ogromnim dijelom planete pridodate su diskriminatorne mjere protiv ne-bijelaca u zemljama u koje su imigrirali.

Prvi svjetski rat uzdigao je Japan u silu prvog ranga među svjetskim nacijama. Carstvo je profitiralo od ulaska u rat 1914. na strani Antante, a protiv Njemačke, ojačavši svoju poziciju na Dalekom istoku i Pacifiku. Japan nije uspio u svojoj namjeri da Društvo naroda usvoji ,,jednakost rasa“ na konferenciji Lige naroda (preteče UN) 1919. ${ }^{11}$ Tokom perioda Hladnog rata, korpus ljudskih prava je široko sagledavan i često medijski i politički korišćen u međunarodnim odnosima od strane suprostavljenih blokova. ${ }^{12}$ Mada često selektivno i u skladu sa partikularnim interesima.

U posthladnoratovskoj doktrini posebno je politika zaštite ljudskih prava postala moćno sredstvo spoljnjeg uticaja na politiku određene zemlje. Tako je 1990. američki predsjednik Buš retorikom "zaštite ljudskih prava, moralnosti, jedinstva,

9 Vjekovima, pod uticajem patrijahata i religijskih dogmi, žene nisu bile ravnopravne sa muškarcima. Novi Zeland je prva država koja je dala ženama pravo glasa 1893., Rusija 1918. dok su SAD to pravo dale tek 1920., Britanija 1928. Čak su i neke evropske države vrlo kasno uvele pravo glasa za žene. Tako ga je Švajarska uvela 1971., a u Aziji Kuvajt 2005. i Saudijska Arabija 2015.

10 Od kraja građanskog rata, Abraham Linkoln je bio poznat kao predsjednik koji je oslobodio robove, njegova namjera tokom građanskog rata je dominantno bila spas američke Unije. Godine 1862. napisao je pismo Horasu Griliju, uredniku "New York Tribune", rekavši: "Da sam mogao da spasim Uniju bez oslobađanja bilo kog roba, to bih i uradio". - više na: https://www.cdm.me/, stranici pristupljeno 22.5.2019.

11 Ipak, cilj Japana nije tada bila jednakost svih rasa. Japanska vlast se plašila da bi inferioran položaj japanskih državljana ugrozio poziciju Zemlje izlazećeg sunca u budućem međunarodnom poretku. U SAD, bijeli južnjaci su se osvetili za poraz u Građanskom ratu stvorivši sistem segregacije i Kju Kluks klan (KKK). Kalifornija je 1854. uvela novi porez za strance nepogodne za naturalizaciju. Na ovaj način planeta je podijeljena na belce i one koji to nisu i rođena je zamišljena zajednica koja je nadilazila nacionalne granice. Američki Senat je u martu 1920. odbio da ratifikuje Versajski sporazum i SAD se nikada nisu učlanile u Društvo Naroda. U decembru 1948., novoosnovane Ujedinjene nacije će u prvom članu Univerzalne deklaracije o ljudskim pravima proglasiti da se „Sva ljudska bića rađaju slobodna i jednaka u dostojanstvu i pravima“" (Miho, 2019; Aydin, 2007).

12 Kao primjer možemo navesti Džekson-Venikov amandman iz 1974. na postojeći Zakon o trgovini, koji je stupio na snagu sledeće godine. Povod je odluka Prezidijuma Vrhovnog saveta SSSR-a da oni sovjetski građani koji emigriraju u inostranstvo, a imaju visokoškolsku diplomu, državi prethodno vrate novac koji je ona uložila u njihovo obrazovanje (to je bilo vrijeme kada su Jevreji masovno odlazili u Izrael). Odluka je protumačena kao udar na ljudska prava i bila je povod da SAD unesu pomenuti amandman, na inicijativu senatora Henrija Džeksona i Čarlsa Venika. Taj amandman zabranjivao je davanje statusa najpovlašćenije nacije, kao i izdavanje kreditnih garancija i kredita uopšte, onim državama koje svojim građanima uskraćuju pravo na emigraciju. Naknadno su važenje tog zakona vlasti SAD proširile i na Kinu, Vijetnam i Albaniju. Sa promjenama u SSSR-u i uopšte u međunarodnim odnosima, 1989. je na amandman Džekson-Venik uveden moratorijum, a 2002. je Vašington zvanično objavio da rusku ekonomiju smatra tržišnom, da bi 21. novembra 2012. Džekson-Venikov amandman bio zvanično ukinut, a Rusija primljena u Svjetsku trgovinsku organizaciju posle gotovo dvije decenije čekanja - više na: https://rs-lat.sputniknews. com/ sto-godina-sankcija-protiv-rusije, stranici pristupljeno 23.4.2019. 
pravde i zakonitosti osigurao uspostavljanje široke vojne koalicije tokom napada na Irak. B. Klinton upravo na zaštiti ljudskih prava temelji praksu humanitarnih intervencija (Somalija 1993.; Haiti 1994.; Bosna 1995.; SR Jugoslavija 1999.;), nakon čega ljudska prava postaju često "upotrebljiva" u geopolitici novog milenijuma. ${ }^{13}$

Putem medijskog promovisanja univerzalnih normi ljudskih prava i sloboda i stavljanjem ciljanog fokusa na one koji ih se ne pridržavaju, već krše ljudska prava, putem masovnih medija se pripremao teren za potencijalne političke i vojne akcije. Intervencionistička politika se odnosi na angažman neke zemlje na teritoriju i/ili u državnim poslovima druge zemlje, a radi ostvarivanja vlastitih nacionalnih interesa. Intervencionizam može biti ostvaren i nevojnim sredstvima, ekonomskim sankcijama ili djelovanjem obavještajnih agencija (Kos-Stanišić, 2000). Kritičari ističu argumenti protiv vojnih humanitarnih intervencija: takva akcija predstavlja ekskluzivno asimetrično pravo jakih država. Intervencionističke države obično nisu motivisane humanitarnim razlozima već nekim drugim, to im je samo povod, sama upotreba vojne sile predstavlja kršenje ljudskih prava, evidentan je slab učinak vojnih humanitarnih intervencija. Političke i ekonomske posledice vojnih intervencija u Avganistanu ${ }^{14}, \operatorname{Iraku}^{15} \mathrm{i}$

13 Njemački sociolog Ulrih Bek, režim zaštite ljudskih prava smatra "vrlo efikasnom strategijom koja "revolucionira svjetski politički poredak", na način da meta-moć globalnog civilnog društva (NVO), kao novog subjekta međunarodnih odnosa, nametanjem pitanje zaštite ljudskih prava urušava autonomiju nacionalne države. Nacionalna ili socijalna prava gube prednost pred režimom zaštite ljudskih prava čime se otvara bezgranični prostor moći svjetske unutrašnje politike u kojem se zapadne, globalno uticajne države, ali i nevladine organizacije vrlo intenzivno miješaju u unutarnju politiku drugih, na način da mogu mijenjati njihove strukture vlasti. Bek govori o "mješovitom obliku humanitarne nesebičnosti i imperijalne logike moći, posebno iskazane $u$ vojnim humanitarnim intervencijama, $\mathrm{i}$ ističe, kako teme globalnog civilnog društva poput zaštite ljudskih prava, često bivaju instrumentalizovane od strane SAD, EU kao i drugih globalnih aktera, na način da postaju vrlo korisna "ideološka oprema za ekonomske i vojne ratove" (Polović, 2017).

14 Procenjuje se da je proizvodnja opijuma u Avganistanu porasla sa 8.000 hektara 2001. na 200.000 hektara 2017. Dakle, od kada je NATO, izvršio invaziju u Avganistanu, proizvodnja opijumskog maka porasla je čak 25 puta. https://www.b92.net/info/vesti/index.php, stranici pristupljeno 25.5.2019.

15 Za neophodnost oružanog odgovora, pored pravnih i ekonomskih, isticani su i humanitarni razlozi zaštite civilnog stanovništva od zločina Iračana 1991. Jedna od najpoznatijih priča takvog tipa je priča o mrtvim kuvajtskim bebama: "Tada se pred Odborom za ljudska prava u SAD pojavila mlada Kuvajćanka, predstavljena kao medicinska sestra, koja je izjavila da su u bolnici u Kuvajtu u kojoj je radila, upali irački vojnici, vadili novorođene bebe iz inkubatora i bacali ih na pod, bebe su pri tome umrle - njih čak 312". Svedočenje ove mlade djevojke izazvao je šok, gnušanje i znatno doprinijelo oblikovanju javnog mnenja u SAD pa i šire u podržavanju vojne akcije. Sam tadašnji predsjednik Buš je u svojim javnim nastupima spomenuo ovo svjedočenje više od 30 puta. Tek 9 mjeseci nakon završetka operacije Pustinjska oluja, koja je protjerala Iračane iz Kuvajta, objavljena je puna istina o ovom slučaju i identitetu mlade Kuvajćanke. Djevojka uopšte nije bila medicinska sestra, već ćerka kuvajtskog ambasadora u Vašingtonu, i nije neposredno došla iz Kuvajta, već je više godina neprekidno boravila u SAD. nije bila nikakav očevidac niti je bilo ikakvih beba ubijenih na takav način Priča je predstavljala veliki propagandni uspjeh firme za javne odnose 
Libiji ${ }^{16}$, te neuspjeh "demokratizacije" ovih država, poništavaju temeljnu ideju "vojnog humanitarizma": zaštitu civilnog stanovništva.

Još je Versajski sporazum 1919. je priznao da je sama agresija bila uzrok Svjetskog rata: Austrija je iskoristila sarajevski atentat kao izgovor i povod za napad na Srbiju, a Njemačka je krenula u agresivni rat napadajući Belgiju i Francusku". Proizilazeći direktno iz ovog priznanja, zabrana agresije je brzo postala glavno načelo međunarodnog prava. Kelog-Brajanov pakt iz 1928. zabranio je agresivne ratove, a okrivljeni u Nirnbergu 1945. bili su optuženi za „zločine protiv mira”. U Povelji UN 1945. zabranjen je napadački rat. ${ }^{17}$

Međutim, strateški imperativi kontrole prirodnih resursa sve vidljivije usmjeravaju tok budućih spoljnopolitičkih akcija globalnih aktera. Naime, posledice ovakve strategije svjetske supersile i njenih saveznika, primjenjene na Balkanu, Iraku, Avganistanu ${ }^{18}$, Libiji, posredno i drugim zemljama Sjeverne i podsaharske Afrike, te Siriji, jesu razorena društva koja svojom nestabilnošću, spolja izazvanim haosom, siromaštvom, civilnim žrtvama i rijekama imigranata ugrožavaju međunarodni mir i sigurnost. Evropa se suočila s poplavom imigranata kao potencijalnih azilanata. Migraciona kriza je samo posledica prethodnih uzroka - geopolitičkih uplitanja spoljnih faktora u politički nestabilna područja Afrike i Azije. Pitanje širenja demokratije i ljudskih prava postaju neobično i široko "upotrebljiva" u geopolitici 21. vijeka. U tom kontekstu zaštita ljudskih pra-

Hill i Knowlton, koja je primila 12 miliona dolara za nekoliko mjeseci rada. Punu istinu je objavio Džon Mekartur u knjizi “Drugi front” (prema Tadić, 2002: 115).

16 Vojnu intervenciju u Libiji 2011. pokrenula je zapadna koalicija predvođena SAD, Velikom Britanijom i Francuskom nakon što je SB UN-a izglasalo Rezoluciju 1973. U knjizi Mitovi, laži i ratovi za naftu, W. Engdahl "humanitarni" rat u Libiji sagledava kao de facto čin neokolonijalizma, koji, s ciljem prisilne promjene režima, krši temeljne norme međunarodnog prava. Autor navodi kako libijski slučaj predstavlja pokušaj uvođenja opasnog koncepta Odgovornosti za zaštitu (The Responsibility to Protect) kao nove norme na polju međunarodne bezbjednosti i ljudskih prava, zbog čega je opravdanje za upotrebu sile i u Libiji utemeljeno na prioritetu zaštite ljudskih prava. - više na: https://www.geopolitika.news/analize/, stranici pristupljeno 20.4.2019.

17 U prvoj presudi Nirnberškog suda 1946. navedeno je: „Započinjanje napadačkog rata nije samo međunarodni zločin; to je vrhovni međunarodni zločin koji se razlikuje od drugih ratnih zločina samo po tome što sadrži u sebi cjelokupno akumulirano zlo.” (više u: „Politika“, 30. jun 2014; O pitanju invazije i ratne okupacije, zašite civilnog stanovništva; Degan, 2000: 894).

18 Projekat za novi američki vijek (Project for New American Century), neokonzervativni tink-tenk, analitički centar čiji je proklamovani cilj bila ,promocija globalnog liderstva Amerike“, godinu dana prije napada 11. septembra je objavio izveštaj pod naslovom „Ponovna izgradnja američke odbrane: Strategija, snage i resursi za novi vijek“, u kome se zagovara pojačano američko vojno prisustvo širom svijeta a navodi se i da je to što oni žele malo vjerovatno „osim u slučaju katastrofalnog i kataklizmičkog događaja - kao što bi bio novi Perl Harbur“. Upravo to, novi Perl Harbur uslijediće 11. septembra 2001, a naročito je važno napomenuti da su čelnici Projekta devet meseci ranije zauzeli važne funkcije u Bušovoj administraciji — Dik Čejni postao je potpredsednik SAD, Donald Ramsfeld sekretar za odbranu, njegov zamenik bio je Pol Volfovic, stručnjak za formiranje javnih narativa. - više na: http://www.newamericancentury.org/, stranici pristupljeno 12.2.2019. 
va postaje formalni temelj intervencionizma, kojim se oblikuju političke prilike u zemljama evropske periferije (Ukrajina, Makedonija, KosMet) ili se na prostoru Sjeverne Afrike i Bliskog istoka nasilno ruše nepodobni režimi, instaliraju novi, doktrinom "kontrolisanog haosa" ili "Odgovornosti za zaštitu".

Kritičari ističu, da se SAD kao "supersila u zalasku", ne susteže od osporavanja suvereniteta ${ }^{19}$ drugih država, nasilnog mijenjaja režima i prekrajanja granica. Ne obaziru se previše na međunarodni poredak niti međunarodno pravo, koristeći emocionalnu argumentaciju u međunarodnim odnosima, često utemeljenu na medijskim manipulacijama, sve se češće odlučuju upotrijebiti silu s ciljem promjene režima. Takva praksa, koja poslednjih decenija postaje pravilo, svoju legitimnost temelji na vrlo fluidnim kriterijima opravdanosti intervencija (Šćekić, 2019: 279). U kontekstu savremenih međunarodnih odnosa, posebno režim zaštite ljudskih prava se koristi kao vrijedan argument za vođenje tzv. pravednih ratova. Odgovornost za zaštitu (The Responsibility to Protect), kao set UN-ovih normi koje koriste SAD i njeni evropski saveznici postupno se kreće prema otvorenom, brutalnom i nasilnom mijenjanju nepodobnih režima s jasnim ciljem ovladavanja energetskim resursima te putevima njihova protoka na području Evroazije i Sjevera Afrike". Naročito nakon 11. septembra 2001. imperativ zaštite ljudskih prava opravdava upotrebu sile i kršenje načela suverenosti država protiv tzv. nepodobnih, ili odmetničkih država, pojam koji su nakon 1990.

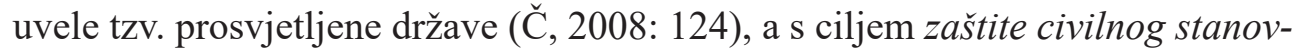
ništva, spriječavanja genocida, etničkog čišćenja kao zločina protiv čovječnost ${ }^{20}$ i sličnih floskula koje se medijski promovišu. ${ }^{21}$

19 Osporavanje i ograničavanje suvereniteta sprovodio je ranije Sovjetski Savez prema svojim satelitima u Centralnoj Evropi, nakon oružanih intervencija u Mađarskoj (1956.) i Čehoslovačkoj (1968.): Lideri Varšavskog pakta su se 3. avgusta 1968., okupili u Bratislavi na zajedničkom sastanku gde se pojavio generalni sekretar Komunističke partije i lider Sovjetskog Saveza Leonid Brežnjev koji je po prvi put proklamovao "Doktrinu ograničenog suvereniteta", kao važan segment nove politike Sovjetskog Saveza prema članicama Varšavskog pakta i ostalim zemljama socijalističkog tabora. Ova doktrina bila je veoma jasna u pogledu suvereniteta neke zemlje, a to znači da neka država može ostati suverena onoliko dugo, ukoliko nema štete po interese ostalih socijalističkih zemalja i država članica Varšavskog pakta. - više na: https://www.ekspres.net/istorija/ pola-veka-od-praskog-proleca, stranici pristupljeno 20.5.2019.

20 Robert MekNamara je bio najuticajniji sekretar odbrane SAD 20. vijeka. Služio je predsjednicima Džonu Kenediju i Lindonu Džonsonu od 1961. do 1968. Karijeru je završio kao predsjednik Svjetske banke. Izjavio je: „Spalili smo na smrt 100.000 japanskih civila u Tokiju - muškarce, žene i djecu, a sveukupno je stradalo oko 900.000 civila u Japanu“. General Kurtis LiMej, koji je vodio vazduhoplovne snage tokom japanskog rata je rekao „Da smo izgubili rat, svi bismo bili procesuirani kao ratni zločinci“ i mislim da je u pravu. Svi smo mi bili ratni zločinci“ rekao je MekNamara (Chomsky, 2006).

21 U američkoj posthladnoratovskoj strategiji ljudska prava sve više postaju politički instrument, vrlo korisno sredstvo utjecaja na unutarnju politiku određene zemlje te postupno formalni temelj američkog intervencionizma - više (Polović, 2017). 
Sam koncept ljudskih prava je liberalan i Zapadni i u njega je ugrađeno razumijevanje ljudskih prava (zakon) i sloboda Zapadnog prosvetiteljstva. Pravo je uspostavljeno kao opšta kategorija, potpuno odvojena od stvarnog postojanja određenog društva i njegovih specifičnosti, posebnosti, tradicije, etnosa, kulture. Nasilno nametanje zapadne kulture i normi kroz formu meke sile ili intervencija dovodi do konflikata. Sâma ova idelogogija je osnova za zapadnjački intervencionizam prem drugim državama i njihovim poslovima, koji ne moraju ni da imaju neke veze sa Zapadom. ${ }^{22}$ Sukob u Angoli koji je tinjao nekoliko decenija tokom druge polovine 20. vijeka, predstavlja karakterističan primjer geopolitičke upotrebe jednog prostora, kroz formu borbe za slobodu i ostvarivanja željenih ljudskih prava (v. Hironaka, 2009). Sličan geopolitički sukob regionalnih geopolotičkih igrača, vodi se danas u Jemenu (sukob Irana i Saudijske Arabije). Dvije organizacije za ljudska prava, Amnesty International i Human Rights Watch zatražile su da se Saudijska Arabija suspenduje iz Savjeta za ljudska prava UN zbog sprovođenja vojne kampanje u Jemenu. ${ }^{23}$ Naravno, u politici se ništa ne dešava "slučajno" ni "spontano", a iako se dogodi - to je unaprijed već dogovoreno, poput "Arapskih proleća". ${ }^{24}$ Dešavanja u Srpskoj pokrajini Kosovo (Kosmet) tokom druge polovine 90-tih godina 20. vijeka, predstavljaju primjer upotrebe rješavanja ljuskih prava, kao povoda za ostvarivanje željenih geopolitičkih ciljeva. ${ }^{25}$ Situacija je, u vezi sa ljudskim pravima u Izraelu, takođe pod medijskom pažnjom, jer većina ilegalno zatvorenih i mučenih su Palestinci. Nasilje nad njima se sprovodi na njihovoj sopstvenoj teritoriji, koja je pod dugogodišnjom izraelskom okupacijom. Teroristička organizacija DA-

22 Ideologija ljudskih prava je Rusiji nametnuta posle raspada Sovjetskog saveza i ogleda se u strukturi novog ruskog zakonodavstva; nakon dolaska na vlast konzervativne vlade Vladimira Putina, pokušalo se sa ponovnim tumačenjem liberalne dogme na konzervativni način. Za Rusiju, osnovno ljudsko pravo je pravo na život u slobodnoj zemlji suverenoj u odnosu na diktat Zapada - https:// www.geopolitica.ru/sr/agenda/nashe-pravo-ljudska-prava-i-rusija, stranici pristupljeno 25.5.2019.

23 U zajedničkom saopštenju za javnost, oni ističu da je Saudijska Arabija, za dvije i po godine od kada je u Savjetu UN za ljudska prava, počinila "brutalana i sistematska kršenja ljudskih prava". Saudijska Arabija je zloupotrijebila svoj položaj i zaustavila nezavisne istrage i kritike o tome kako je ta zemlja započela rat u Jemenu. U saopštenju se navode i slučajevi kršenja ljudskih prava i u sâmoj Saudijskoj Arabiji, uključujući zatvaranje disidenata i diskriminiciju radnika-imigranata, žena i šiitske manjine. Navodi se dalje da se talas pogubljenja u Saudijskoj Arabiji pojačao otkad je zemlja član Saveta za ljudska prava UN - Saudijska Arabija i Savjet za ljudska prava UN - dostupno na: https://www.geopolitica.ru/sr/article/oksimoron-un-saudijska-arabija-i-savet-za-ljudska-prava-un. U Saudijskoj ambasadi u Istanbulu, ubijen je 2018. saudijski novinar Kašogi.

24 Kako ističe visoki francuski oficir u vezi sa organizovanim dešavanjima u Arapskom svijetu: „Masovno smo uništili infrastrukturu i stanovništvu ponudili odvratnu sliku onoga što bi moglo da bude oslobađanje u zapadnom stilu koje iza sebe ostavlja sjeme pobune koju odmah može da povede novi protivnik“, naveo je Legrije, F. National defense rewiev, „Top French officer raps West's tactics against IS in Syria, faces punishment" - više na: https://www.reuters.com/article/us-germany-security-france-syria/top-french-officer-raps-wests-tactics-against-is-in-syria, stranici pristupljeno 22.5.2019.

25 Više u: Nation, 2003; Kyril, Gokay, Waller, 2014:176. 
EŠ držala je pod okupacijom dio teritorije Sirije i Iraka. Opisana su brojna ubistva, mučenja, seksualno nasilje, porobljavanje ljudi, kidnapovanja. Uopšteno uzevši, geografija mučenja pokazuje stabilnu težnju ka političkoj polarizaciji. Tortura se sprovodi u državama koje, s jedne strane, kao $\mathrm{SAD}^{26} \mathrm{i}$ Izrael, promovišu vladavinu prava, a sa druge strane u državama u kojima postoji nagla transformacija političkog sistema. U ovim slučajevima, liberalno-demokratske institucije se koriste kao "kišobran" kojim se opravdava nasilje. ${ }^{27}$

U savremeno doba, upotreba nasilja je prerogativ države. Kako je Maks Veber naveo, ,jedino država ima pravo da sprovodi nasilje“. Institucionalizacija nasilja je počela $u$ isto vrijeme kada su demokratske institucije osnovane. Pravno tumačenje raznolikih "okrutnosti" u SAD krajem 18. i početkom 19. vijeka je odobravalo i opravdavalo nasilje od strane države. U Masačusetskom "habeas corpus" iz 1841. se kaže da osuđeni kriminalac može biti mučen ako je kriv, ali „mučenje ne smije biti varvarsko ili nehumano“. ${ }^{28}$ Pitanje ljudskih prava i sloboda steklo je jasnu geopolitičku komponentu, a poslednjih decenija sve češće postaje izgovor za političko-ekonomske i vojne konflikte. U poslednje dvije decenije ustalio se izraz „humanitarna intervencija“, što podrazumijeva miješanje spolja u neki unutardržavni konflikt u cilju “zaštite ljudskih prava”. U politici vodećih sila, na vrlo složen način su isprepletani i normativni i praktični motivi, vezani za osiguranje svojih nacionalnih političkih ekonomskih interesa.

26 SAD su nakon 11.9.2001. sistemski sprovodili torturu, držeći zarobljene islamiste u vojnoj bazi Gvantanamo na Kubi, ali i u tajnim zatvorima u Rumuniji i Poljskoj, što je bila tema medijskih skandala.

27 "Posebno su u SAD i Izraelu programi torture povezani sa izgovorom nacionalne bezbjednosti. U slučajevima narušenih država, kao što su Irak ili Ukrajina, izlivi nasilja su povezani sa razdvajanjem države od njenih društvenih obaveza, uključujući i one da zaštiti živote, prava i slobode građana, i sa geopolitičkim interesima trećih strana. U Ukrajini je sprovođena namerna nacifikacija i revizionizam, kako bi se u društvu stvorila klima rusofobije i slijedile zakonodavne aktivnosti u zemlji, koje jedino idu na ruku Vašingtonu“ - više na: https://www.geopolitica.ru/sr/article/geopolitika-muchenja, stranici pristupljeno dana 12.2.2019.

28 "Konvencija protiv nasilja iz 1984. se širi izvan definicije mučenja kao nehumanog čina i definiše ga kao nelegalno mučenje. Prema ovom tumačenju, onda, svaki čin koji je proglašen legalnim, nije mučenje. Stoga, ako vlasti imaju moć da deluju u ime nekih apstraktnih interesa nacionalne bezbednosti,, mogu da muče osumnjičene, jer im to dozvoljava zakon. Odsjek za pravnu pomoć američkog Ministarstva pravde je čak, na zahtev CIA, pripremio dokument u kome se kaže da, ako će državni zaposlenik da muči zarobljene i osumnjičene za terorizam, on to mora da čini kako bi spriječio nove napade teorirstičke mreže al-Kaida u Sjedinjenim državama. Džordž Tenet, šef CIA od 1997. do 2004. je lično odobrio okrutne tehnike ispitivanja, uključujući i razne metode davljenja u vodi. Tenet je bio zadužen da unaprijedi, promijeni ili odbaci sve predloge u vezi sa istraživanjima koja uključuju "humane subjekte". Najneslavniji slučajevi iz ovog programa u poslednjih par godina, jesu mučenje iračkih zatvorenika u zatvoru Abu Greb i smještanje u specijalne zatvore mnogobrojnih osumnjičenih stranaca povezanih sa Al-Kaidom, od kojih se većina i dalje nalazi u američkoj vojnoj bazi u Gvantanamu (i to na kubanskoj teritoriji, koju su SAD okupirale 1959.)“ (Foley, 2003; Geopolitika mučenja https://www.vesti.rs/Politika/Geopolitika-mucenja.html, stranici pristupljeno dana 12.2.2019.) 
Nakon 11. septembra 2001. humanitarne intervencije poprimaju formu rata protiv terorizma koji direktno dovodi u pitanje suverenitet ${ }^{29}$ tzv. "odmetničkih država". Rangirajući druge države prema njihovoj "spremnosti za poštovanjem ljudskih prava i vjerskih sloboda", $\mathrm{SAD}^{30}$ su često i unilateralno (jednostrano) intervenisala u lokalne konflikte primjenjujući američke zakone eksteritorijalno na području drugih država. Mediji imaju ključnu ulogu u promovisanju ljudskih prava i izgradnji društva tolerancije i zato je potrebno unapređivati njihov rad. Različitost mišljenja zasniva se na toleranciji.

Ono što uopšteno karakteriše međuetničke i međuvjerske sukobe, kako Bliskog istoka tako i prostora Jugoistočne Evrope jeste problem "mržnje malih razlika". Jer, što je bliskost (jezička, genetska, etnička, kulturna) veća - to je animozitet i sukob među takvim zajednicama jači. Kao karakteristične primjere možemo navesti prostor Palestine, Ukrajine, Balkana. Ove male razlike (jezičke, vjerske, karakterne, kulturne) se iz geopolitičkih centara moći namjerno i ciljano produbljuju. Po obrazcu "zavadi pa vladaj”. Stvaraju se krizna žarišta koje potom geopolitički centri mire i šire ekonomske i političke reforme, namećući nove kulturne obrazce i željeni korpus ljudskih prava.

\section{Zaključna razmatranja}

Masovni mediji, u prvom redu internet i televizija igraju jednu od ključnih sredstava u procesu nove geopolitičke prekompozicije u novom milenijumu. Druga decenija novog milenijuma donijela je zaoštravanje medijskog diskursa na globalnom nivou. Savremena dešavanja na Bliskom istoku i Evropi navode na razmišljanje: u kojoj mjeri su ona rezultat spontanih procesa, a u kojoj mjeri su vještački izazvani sa strane? U toku je geopolitička borba, u kojoj se radi ostvarivanja određenih političkih i ekonomskih interesa, prema ciljanim državama koriste različita sredstva po modelu "kontrolisanog haosa". Korpus ljudski prava se široko koristio i koristi u cilju ostvarivanja željenih geopolitičkih interesa. U te svrhe se koriste masovni mediji, ekonomske sankcije, hibridni rat, humanitarne vojne intervencije. Suđenje za kršenje ljudskih prava od Nirnberga do Haga, daje osnova i za optužbe da

29 CIA je 2003. kidnapovala Milanskog imama, Abu Omara, i prevezla ga u Egipat. Svještenik Abu Omar je mučen zbog navodnih veza sa islamistima. Nakon protesta javnosti, italijanski sudovi su optužili preko 26 agenata CIA i mnoge druge zbog ovog događaja i međunarodnog skandala. - više na: http://www.watchingamerica.com/, stranici pristupljeno 27.3.2019.

30 "SAD ne smeta da proklamuje neke svoje posebne nacionalne i državne interese i da jednostavno zaobiđu međunarodne pravne norme uopšte. Na jednoj konferenciji u Bratislavi, krajem aprila 2000. američki predstavnik je na samitu NATO-a i novih kandidata za članstvo u NATO rekao: „Tamo gdje međunarodno pravo stoji na putu ostvarivanja interesa NATO-a i interesa SAD, treba ga ukloniti.“ - više u Jovanović, Ż. https://rs-lat.sputniknews.com/intervju/Zivadin-Jovanovic, stranici pristupljeno 27.5.2019. 
se međunarodni sudovi zloupotrebljavaju u cilju selektivnog odabira žrtava i okrivljenih u skladu sa određenom politikom. Primjeri kršenja ljudskih prava u Ruandi, Argentini i na prostoru bivše Jugoslavije, daju osnova za takve kritike. Čest je i obrazac: dopustiti kršenje prava, a onda se pozvati na stvorenu faktičku situaciju kao pravni osnov za intervenciju. Za njih pak nužno trebaju podršku javnosti, i zato u medije lansiraju određenu propagandu koja opravdava takva djelovanja.

\section{Literatura}

- Aydin, C. (2007) The Politics of Anti-Westernism in Asia: Visions of World Order in Pan-Islamic and Pan-Asian Thought. New York: Columbia University Press.

- Chomsky, N. (2006) Imperijalne težnje. Zagreb: Naklada Ljevak.

- Čehulić, L. (2010) Euroatlantizam. FPZ: Zagreb.

- Degan, V.Đ. (2000) Međunarodno pravo. Rijeka: Pravni fakultet Sveučilišta u Rijeci.

- Engdahl, F. W. (2009) Full Spectrum Dominance: Totalitarian Democracy in the New World Order. Edition.Engdahl.

- Foley, C. (2003) Combating torture. London: Human Rights Centre. University of Essex.

- Hironaka, A. (2009) Neverending Wars: The International Community, Weak States, and the Perpetuation of Civil War. Cambridge, MA: Harvard University Press.

- Kos-Stanišić, L. (2000) Vojne komponente američke vanjske politike. Polemos, 3(1), str. 111-140.

- Kyril, D., Gokay, B., Waller, M. (2014) Kosovo: the Politics of Delusion. New York: Routledge.

- Kovačević, F. (2005) Teoretičari klasične geopolitike. Podgorica: CGO.

- Nation, R. C. (2003) War in the Balkans, 1991-2002. US: Strategic Studies Institute, US Army War College.

- Šćekić, R. (2019) Mediji i geopolitika. Nikšić: Medijska kultura.

- Tadić, M. (2002) Osnove međunarodne propagande. Beograd: BINA.

\section{Internet izvori:}

- Geopolitika mučenja, https://www.vesti.rs/Politika/Geopolitika-mucenja.html, stranici pristupljeno dana 12.2.2019.

- Goldsmith, J. (2018) The 'deep state' is real. But are its leaks against Trump justified? The Guardian. - dostupno na: https://www.theguardian.com/com- 
mentisfree/2018/apr/22/leaks-trump-deep-state-fbi-cia-michael-flynn, stranici pristupljeno 12.5.2019.

- https://rs-lat.sputniknews.com/sto-godina-sankcija-protiv-rusije, stranici pristupljeno 23.4.2019.

- https://www.b92.net/info/vesti/index.php, stranici pristupljeno 25.5.2019.

- https://www.cdm.me/, stranici pristupljeno 22.5.2019.

- http://www.ceopom-istina.rs/, stranici pristupljeno 12.5.2019.

- https://www.ekspres.net/istorija/pola-veka-od-praskog-proleca, stranici pristupljeno 20.5.2019.

- https://www.ekspres.net/uncategorized/duboka-drzava, stranici pristupljeno 12.5.2019.

- https://www.geopolitika.news/analize/, stranici pristupljeno 20.4.2019.

- https://www.geopolitica.ru/sr/agenda/nashe-pravo-ljudska-prava-i-rusija, stranici pristupljeno 25.5.2019.

- https://www.geopolitica.ru/sr/article/geopolitika-muchenja, stranici pristupljeno dana 12.2.2019.

- https://www.geopolitica.ru/sr/article/oksimoron-un-saudijska-arabija-i-savet-za-ljudska-prava-un

- http://www.newamericancentury.org/, stranici pristupljeno 12.2.2019.

- https://www.reuters.com/article/us-germany-security-france-syria/top-frenchofficer-raps-wests-tactics-against-is-in-syria, stranici pristupljeno 22.5.2019.

- http://www.watchingamerica.com/ stranici pristupljeno 27.3.2019.

- Jovanović, Ž. https://rs-lat.sputniknews.com/intervju/Zivadin-Jovanovic, stranici pristupljeno 27.5.2019.

- Lofgren, M. (2014) Essay: Anatomy of the Deep State. Bill Moyers.com. Retrieved 2018. - dostupno na: https://billmoyers.com/2014/02/21/anatomy-ofthe-deep-state/

- Miho, M. (2019, 5.april) Kako je Društvo naroda odbacilo jednakost rasa 1919, Nedeljnik - dostupno na: https://www.nedeljnik.rs/kako-je-drustvo-naroda-odbacilo-jednakost-rasa-1919/

- Munich Security Conference (2017) Munich Security Report. Minhen - dostupno na: https://www.securityconference.de/debatte/munich-security-report/, stranici pristupljeno 26.5.2019.

- NATO (2014) Встреча на высшем уровне 1990 года: поворотный момент

- в отношениях между Востоком и Западом. - dostupno na: https://www.nato.int/cps/ru/natohq/news_116133.htm? selectedLocale=ru, stranici pristupljeno 11.6.2019. 
- Polović, J. (2017) Etički aspekti Američkog intervencionalizma, Geopolitika.news - dostupno na: http://geopolitika.news/analize/, stranici pristupljeno 25.4.2019.

- Polović, J. (2017) Ljudska prava kao formalni temelj intervenističkih politika. Geopolitika.news - dostupno na: https://www.geopolitika.news/, stranici pristupljeno 12.5.2019.

- Sudar svetova - dostupno na: https://www.vesti.rs/, stranici pristupljeno 17.4.2019.

\author{
Radenko ŠĆEKIĆ, PhD \\ Historical institute, University of Montenegro \\ Senior research associate
}

\title{
USE OF HUMAN RIGHTS FOR GEOPOLITICAL PURPOSES
}

The Human Rights corpus has been widely used and is used to pursue the desired geopolitical interests. Mass media, economic sanctions, hybrid war, humanitarian military interventions are used for these purposes. In this context, the protection of human rights becomes the formal basis of interventionism, which shapes political opportunities in many countries. Through the media promoting universal norms of human rights and freedoms and placing a targeted focus on those who do not adhere to them, the ground for potential political and military action was being prepared through the mass media. Geopolitical changes and the Great Powers, in accordance with their particular interests, influence the use of human rights as a pretext for interventions in other countries. Such interventions are often contrary to international law and the UN Charter.

Key words: human rights, geopolitics, media, humanitarian interventions, international law 